\title{
PROMOC̣OEES CULTURAIS
}

Conferência inaugural proferida no dia 15 de fevereiro de 1984 pelo Prof. Roberto José Vernengo, Diretor do Departamento de Pós-Gradua- 
ção e do Instituto de Filosofia do Direito da Faculdade de Direito da Universidade Nacional de Buenos Aires, sobre o tema A Filosofia Analítica e a Metodologia do Direito.

Conferências proferidas nos dias 24 e 25 de setembro pelo Prof. Dr. Winfried Hassemer, da Universidade de Frankfurt, República Federal da Alemanha, sobre os temas: "Quão Livres são os Juízes sob a Lei?" e "Possibilidades e Limites do Direito de Resistência na Atualidade".

Palestra realizada no dia 17 de outubro pelo Prof. Caio Tácito, da Universidade do Estado do Rio de Janeiro, sobre o tema "Responsabilidade Civil do Estado".

Exposição apresentada pelo Prof. Eduardo de Oliveira Leite, da Fundação Universidade Estadual de Maringá, no dia 10. de dezembro de 1984, versando temas ligados à Preparação da Monografia Jurídica. 